ARTICLE / ARAŞTIRMA

\title{
The Impact of Multi-Sport Events on the Developmental Dynamics of Cities: the Case of Erzurum, Trabzon and Mersin in Turkey
}

\section{Türkiye'deki Çoklu Spor Organizasyonlarının Kentlerin Gelişimine Etkileri: Erzurum, Trabzon ve Mersin Örnekleri}

\author{
Servet Karaca, Burak Beyhan \\ Department of City and Regional Planning, Mersin University Faculty of Architecture, Mersin, Turkey
}

\begin{abstract}
Nowadays, in Turkey as well as in other parts of the world the tendency of hosting mega events has increased owing to the employment of particularly branding promotion, marketing, and attracting investment funds as a tool for the local and regional development. This strategy has become an important tool of urban and regional development in the countries suffering from de-industrialization, and it has been widely used in the respective countries to trigger the economic development for the last 30 years. Some of the cities in Turkey have been hosting some of these international events since the mid 2000s. Within this context, this study elaborates the impacts of Erzurum, Trabzon and Mersin multi-sport events recently hold in Turkey. Overall, in this paper, it is aimed to unveil the extent of the rapid urban development and transformation desired by the central and local governments with the help of the mega events by focusing on the effects of the events concerned in the respective cities. The study portrays the physical, economical and socio-cultural change and transformations in urban fabric and space before, during, and after the Games period. By focusing on the planning and management of the projects realized in order to hold the events, the opportunities created for the development of the cities hosting the events will be examined within a critical context. The impact of such mega-events on the urban change are explored in terms of not only planning and management of the projects, but also the proper use and management of the infrastructures built as part of these events
\end{abstract}

Keywords: Mega events; multi-sport events; sports-led regeneration; Turkey (Trabzon, Erzurum and Mersin); urban-regional development.

\section{ÖZ}

Günümüzde, dünyanın başka bölgelerinde olduğu gibi Türkiye'de de büyük ölçekli etkinliğe ev sahipliği yapma eğilimi, özellikle markalaşma, tanıtım, pazarlama ve yatırım fonlarını, yerel ve bölgesel kalkınmanın bir aracı olarak kullanılmasıyla artmıştır. Bu strateji sanayisizleşme sorunu yaşayan ülkelerde kentsel ve bölgesel kalkınmanın önemli bir aracı haline gelmiştir ve ilgili ülkelerde son 30 yıldır ekonomik kalkınmayı tetiklemek için yaygın olarak kullanılmaktadır. Türkiye'de kentlerin bazıları, 2000'li yılların ortasından itibaren bu uluslararası etkinliklere ev sahipliği yapmıştır. Bu kapsamda, bu çalışma Türkiye'de son yıllarda gerçekleştirilen Erzurum, Trabzon ve Mersin çoklu-spor etkinliklerinin etkilerini irdelemektedir. Genel olarak, bu çalışmada, bu büyük etkinliklerin düzenlendikleri kentlerde yarattıkları etkilere odaklanılarak, merkezi ve yerel yönetimlerce söz konusu etkinlikler yardımıyla yaratılması istenilen hızlı kentsel gelişme ve dönüşümün kapsamının ve gerçekleşme düzeyinin aydınlatılması amaçlanmaktadır. Çalışma, oyunlar öncesinde, boyunca ve sonrasında kent dokusundaki ve mekanındaki fiziksel, ekonomik ve sosyo-kültürel değişim ve dönüşümleri resmetmektedir. Etkinlikleri gerçekleştirmek için yapılan projelerin planlama ve yönetimine odaklanılarak, etkinliklere ev sahipliği yapan şehirlerin gelişimi için yaratılan fırsatlar eleştirel bir bağlam içinde ele alınacaktır. Bu tür büyük organizasyonların kentsel değişim üzerindeki etkisi, sadece projelerin planlanması ve yönetimi değil aynı zamanda bu olayların bir parçası olarak inşa edilen altyapıların doğru kullanımı ve yönetimi açısından da incelenmiştir Anahtar sözcükler: Büyük etkinlikler; çoklu spor organizasyonlarl; spor eksenli yenileme; Türkiye (Trabzon, Erzurum ve Mersin); kentsel-bölgesel gelişim.

The earlier versions of this paper were presented in the $4^{\text {th }}$ Urban and Regional Research Network (KBAM) Symposium held in Mersin and in the $55^{\text {th }}$ European Regional Science Association (ERSA) Congress held in Lisbon.

Received: 02.12.2015 Accepted: 12.12.2016

Available Online Date: 27.12.2016

Correspondence: Servet Karaca. e-mail: skservetkaraca@gmail.com
TMMOB

Şehir Plancıları Odası 


\section{Introduction}

As in other regions of the world, there is a tendency to host mega events in Turkey. This trend is seen as a tool for local and regional development, and events are implemented with branding, promotion, marketing and attracting investments in mind. In Turkey cities have been hosting particularly 'multisport organizations' such as 'Summer and Winter Games'. It can be argued that with the help of these events a "sports-led regeneration" tricking the urban development is observable in the cities hosting these organizations.

Over the last 20 years debates are going on about the effects of the Olympic and other multi-sport organizations as well as other mega events on urban layout and development. It is known that the Olympic and other multi-sport events contribute a lot to the development of the cities hosting the events concerned. In this respect, there are debates about the effects of the Olympic and other multi-sport events as well as other mega-events on urban and regional spatial development. As a result of these international mega events, cities hosting the events have received a considerable amount of capital flow which is particularly invested in multi-purpose facilities, including infrastructural and cultural projects in order to both meet the requirements of the visitors participating to the events concerned, and also to build the legacy of these events. Nevertheless, after holding these events, the sport and cultural facilities created by the investments made in the cities concerned are not properly utilized, and an effective, efficient and sustainable use of these investments present an ongoing challenge.

Indeed, it was observed that, in parallel with this trend, many mega and "multi-sport events" have been held in different cities in Turkey over the last decade: "2005 İzmir World University Summer Games", "istanbul 2010 European Capital of Culture", "Trabzon 20II European Youth Olympic Games", "Erzurum 201I World University Winter Games", "2013 Mersin 17 th Mediterranean Games", and finally "Antalya 2016 EXPO" are international mega events organized in this period. Also, it is known that in line with these initiatives Izmir has a candidacy for EXPO 2020 (Penpecioğlu, 2013; Edizel, 2014). In addition to this, the government has plans to host 2020 Summer Olympics and 2020 European Olympics.

Mega events are also seen as a tool for urban transformation. These events offer a way out of problems of post-industrial urban economy, and contribute to the country's development, especially in regional scale (Gratton, Shibli and Coleman, 2005; Karaca, 2012:30; Penpecioğlu, 20I3; Edizel, 20I4:33). Host cities try to accelerate urban development with the help of these events. In these events, urban image and identity are reshaped, urban infrastructure is renewed, urban plans are revised and urban space is restructured. Thus, the transformative effects of these events are indisputable. They may also have a significant impact on the local community hosting these events. It is possible to argue that these impacts have reflections in the urban landscape, infrastructure, in the social structure and culture of the city (Roche, 2000; Hughson, 2004; Silk and Amis, 2005). Mega events can be also seen as initiatives frequently implemented by a city so that the city could have a say on global scale.

All over the world, mega-events are marketed as savior events; they are organized to display the strength of the country. The country aims to promote investment objectives with these activities. Also, these events are regarded as a springboard for urban and regional development. They inevitably lead to a number of changes in the urban layout. These effects begin with physical structure of the city, such as construction facilities, and continue with economic and socio-cultural changes. Within this context, this paper aims to analyze to what extent urban development and transformation has been achieved in Turkey via similar events over the last decade. In order to draw a general framework, in the subsequent section, mega events are conceptualized as a form of intervention to urban order, which reveals the contribution of and expectation from these events in local and regional development. The third section presents the development of multi-sport events in Turkey together with the methodological framework employed in this study and the findings from the field surveys conducted in Trabzon, Erzurum and Mersin. The last section provides some concluding remarks by re-elaborating the findings from the field surveys within the framework of expectations from the Games in relation to their contribution to local and regional development.

\section{Mega Events As Interventions for Urban Order}

Today "culture" themed events and activities play an important role in restructuring the city economy (Zukin, 2000; Özdemir, 2005; Dündar, 20I0; Karaca, 2012). One of the approaches becoming popular in revitalization of the local economy, especially in England, has been Mega Events since 1980s (Roche, 2000; Coaffee, 2008; Smith, 2010). Mega events are important components of urban and regional development, and the impacts of the respective events have been a lively discussion topic (Essex and Chalkley, 2004; Smith, 2012). The cities all over the worlds have started to compete to host international, cultural, sportive and Olympic activities. Promotion marketing strategy includes slogans such as "City of Culture", "Olympic City" and "Capital of Culture", "Capital of Sports".

Mega-events cover a wide field of actions and processes. These processes include rapid decision making, city's adop- 


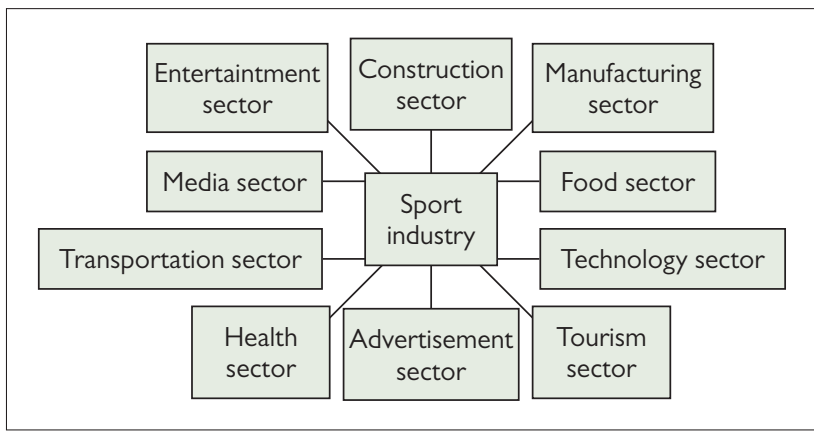

Figure I. Relation of sport industry with other sectors (Devecioğlu, 2005:5)

tions of these activities and flexibility of transformation. As Erten (2012: 2I) remarks, despite their short duration, the effects of mega-events on the city and urban events are long lasting. With these effects in mind, mega events should be thoroughly discussed so as to determine the use of those investments in an efficient way after the events. The contributions of these kind of large events at local, national and international scale can be listed as follows:

- Promotion and advertising,

- Investment, and soliciting/raising funds,

- Urban landscape renewal,

- The development of sports tourism,

- Acquisition of facilities and sporty infrastructure in the city,

- The strengthening of structures,

- The development of sports culture,

- Urban transformation and improvement,

- Diversification of development policies.

As an example of economic impacts of similar events on the host cities, urban construction and tourism sectors can be mentioned. In addition, it is expected that these events would ensure the flow of resources to the cities and increase quality of life, renewing cities. This reinforces the positive impact on investors, increasing public motivation for the projects planned for the city. As a result, the cities enter a re-building process thanks to the Games, and this leads to an increase in income with the distribution of venues over urban space. The relation of sport industry with other sectors is given in Figure I.

One of the issues to which the International Organizing Committee (IOC) attaches importance is to leave an Olympic legacy in the hosting city (see Table I.) An example of this legacy is the sustainability of the Game's heritage in a positive or negative way. As examples of adverse Olympic heritage problems such as debt originated from construction activities, high costs, constructions not needed after the event, environmental destruction, tourists loss, the increase in real estate leasing, the forced displacement of disadvantaged groups as well as unjust distribution of the population can be mentioned (Özdan, 2013; Müller, 2015).
Table I. Grouping physical infrastructure investments made for the olympic games

\begin{tabular}{l}
\hline Direct investments \\
Basic infrastructure \\
Stadium \\
Indoor and Outdoor Sports halls/areas (swimming pool, \\
shooting range, horse-riding areas, canoe-paddling trails, \\
bicycle velodrome etc ...) \\
Secondary infrastructure \\
Olympic village to accommodate athletes \\
Media village/area for members of media \\
Media/press broadcasting center \\
Training areas \\
Parking areas
\end{tabular}

\section{Indirect investments}

Tertiary infrastructure

Transportation (rail systems and roads, stations, airport

facilities etc ...)

Tourism (accommodation, amusement spots in the city/ places etc ...)

Basic urban infrastructure (sewer, telephone / internet lines,

fiber optic cables... etc)

The city center renovation/restoration

Source: Erten, (2012: 17).

Negative examples left by mega-events are generally called with the term, "White Elephant"; this term refers to unused or little used investments remaining idle after the events. Sydney Olympic Park in Australia and Tokyo Saitama Stadium in Japan can be considered as examples of white elephants. Ataturk Olympic Stadium in İstanbul can also be mentioned as a "White Elephant".

Large-scale events are important for the promotion of the country; however, the 1976 Montreal and the 1984 Los Angeles Olympics caused great economic losses (Erten, 2005). Also, the 2004 Athens Olympics and the 2006 Turin World Winter Olympics expenses badly affected the budget in Greece and Italy. Especially with unfolding economic crisis the Games became particularly questionable.

Thus, to what extent the Games could be effective to meet the expectations, and contribute to the development of local and regional infrastructure and development is an important question. Overall following problems have been observed in mega events:

I. Incompatibility with the existing urban development plans.

2. Wrong decisions about the places of venues.

3. Idle venues after the events.

4. Lack of planning for use of venues after events.

5. Lack of integration of infrastructure obtained via events with the existing services in the city after events. 
Table 2. The sport events, the multi-sport events and the mega-events held in Turkey in recent years

\section{Events}

I Eurovision Song Contest 2004, Istanbul,

2 Formula I Istanbul Park, 2005-20I I

3 UEFA Champions League Final 2005, Istanbul,

4 World University Summer Games (Universiade) 2005, Izmir

5 Ist Black Sea Games, Trabzon, 2007

6 UEFA Cup Final 2009, Istanbul

7 European City Of Culture 2010, Istanbul

8 FIBA World Championship 2010, Istanbul, Ankara, Istanbul, Izmir, Kayseri

9 World University Winter Games (Universiade) 20I I, Erzurum

10 European Youth Summer Olympic Festival (EYOF) 201I, Trabzon

II World Wrestling Championships 20II, Istanbul

12 IAAF World Indoor Championships 2012, Istanbul

13 The European Capital of Sports 2012, Istanbul

14 Turkish Airlines World Golf Final 2012, Antalya

15 World Deaf Beach Volleyball Championships 2012, Antalya

$1617^{\text {th }}$ Mediterranean Games 2013, Mersin

17 FIFA U 20 World Cup 2013, Istanbul, Bursa, Antalya, Trabzon, Gaziantep, Kayseri, Rize

I8 $19^{\text {th }}$ European Veterans Athletics Championship 2014, Izmir

19 Expo Antalya 2016

\section{Development of Multi-Sport Events in Turkey} and Methdological Framework of the Study for Trabzon, Erzurum, Mersin Field Research

Turkey's First Five-Year Development Plan (1963-1967) includes the following statement: "The necessary analysis and research will be implemented in our country at certain times for festivals and olympic events during second five-year plans" (SPP, 1963). Concurrent to this, in fact İzmir Mediterranean Games took place in 1971 for the first time in Turkey. However, the process of hosting mega-events was subsequently interrupted. Fortunately, this process resumed with the events implemented over the last decade. The mega-events held in Turkey in recent years are given in Table 2.

Starting with the candidacy process, mega-events require a complex internal discipline during and after the period of events. These have physical, economic and socio-cultural impacts on urban space, and with these aspects they are an important topic appearing in the agenda of city policies. These events should be prepared within the framework of a holistic plan and policy due to the long-term effects in urban areas.

The subject of this study is the sports events which were held in Erzurum, Trabzon and Mersin. The first one is the $25^{\text {th }}$ Universiade organized in Erzurum between 27 January and 6 February 201 I. Universiade, Winter University Games, is an event organized by the International University Sports Federation (FISU) every 2 years (Erzurum20II). The second one is Trabzon 20II European Youth Olympic Games (EYOF), which is an event organized by European Olympic Committee (EOC) (Trabzon20I I). As the first sportive event organized in Turkey at Olympic level, Trabzon 201I EYOF Olympic was organized between 23-30 July $201 \mathrm{I}$.

Finally, Mersin hosted the Mediterranean Games, a multi sport event organized by International Mediterranean Games Committee (UAOK) for countries around the Mediterranean every four years. These Games took place for the second time in Turkey, following the 6. Mediterranean Games held in İzmir in 1971 (Mersin 2013). The statistics for these sports events are given in Table 3.

This paper concentrates on physical, economic and sociocultural impacts of these events on the development of the cities of Erzurum, Trabzon and Mersin. An in-depth field

Table 3. The general statistics of Erzurum, Trabzon and Mersin events

\begin{tabular}{lccccc}
\hline Events & $\begin{array}{c}\text { Number of } \\
\text { participating countries }\end{array}$ & $\begin{array}{c}\text { Number } \\
\text { of athletes }\end{array}$ & Branch & \multicolumn{2}{c}{$\begin{array}{c}\text { Venues } \\
\text { (new+renewal=total) }\end{array}$} \\
\hline Erzurum & 53 & 1,768 & $1 \mathrm{I}$ & $8+2=10$ & $562,151,000.00^{\prime} \mathrm{TL}$ \\
Trabzon & 49 & 3,300 & 9 & $3+12=15$ & $302,818,428.00^{2} \mathrm{TL}$ \\
Mersin & 24 & 3,069 & 32 & $1 \mathrm{I}+43=54$ & $382,061,349.00^{3} \mathrm{TL}$ \\
\hline
\end{tabular}

Source: The Youth and Sport Directorates of Erzurum, Trabzon and Mersin Provinces.

'The Youth and Sport Directorates of Erzurum Province; ${ }^{2}$ The data for the total cost of the venues used in the Games organized in Trabzon is obtained from the following web page of the Grand National Assembly of Turkey: http://www2.tbmm.gov.tr/d24/7/7-0245c.pdf; ${ }^{3}$ The data for the total cost of the venues used in he Games organized in Mersin is obtained from the following web page of the Grand National Assembly of Turkey: http://www2.tbmm.gov.tr/d24/7/7-21960c.pdf. 
Table 4. Event analysis perspectives

\begin{tabular}{ll}
\hline A multi-sport event analysis perspective & Alternative event analysis perspectives \\
\hline Context based & Functionalist and instrumentalist \\
\hline The dramatological dimension & \\
$\quad$ Event core & Ethnographic \\
Experiences and meanings & Textualist \\
Agency & Cultural functionalist \\
The intermediate dimension & \\
$\quad$ Intermediate event zone & Contribution to urban-regional development \\
Event production and consumption processes & \\
Critical political sociological analysis & Economic functionalist \\
The macro-context dimension & Political instrumentalist \\
Event horizon & Critical functionalist \\
Structural change & \\
Historical periodisation & \\
\hline
\end{tabular}

Source: Adapted from Roche (2000: II).

Table 5. Event analysis perspectives employed in the study

\begin{tabular}{|c|c|}
\hline Context & It's impact \\
\hline The dramatological dimension & $\begin{array}{l}\text { The meanings of the events as a drama and action arena, } \\
\text { Faulty lines or important points }\end{array}$ \\
\hline $\begin{array}{l}\text { The intermediate dimension } \\
\text { a) Overall impact on local development } \\
\text { b) Infrastructure acquired with the games }\end{array}$ & $\begin{array}{l}\text { Problems before, during, and after events, } \\
\text { The way to include the city into the Games, } \\
\text { The influences on urban policies } \\
\text { Whether or not the subsequent use of venues were planned beforehand }\end{array}$ \\
\hline $\begin{array}{l}\text { The macro-context dimension } \\
\text { c) Contribution of the process to urban culture, social and } \\
\text { spatial texture of the city, the sport infrastructure and } \\
\text { sport culture considering the long term structural changes } \\
\text { d) Insufficiencies and disadvantages in the long term }\end{array}$ & $\begin{array}{l}\text { Whether or not infrastructure problems were fixed and the extent to } \\
\text { which the expectations for quality of life were met, } \\
\text { Concerns about the future of facilities, } \\
\text { Ability to use the gained infrastructure. }\end{array}$ \\
\hline
\end{tabular}

research and interviews were conducted in order to assess the contribution of these events that were organized on different scales and scopes to the cities concerned. Actually as suggested by Roche (2000), a particular and comparative sociological analysis of mega sport events organized in Turkey is done in the paper by using different levels of analysis (see Table 4. for the method of analysis suggested by Roche (2000) for a comparison of the respective method with the alternative perspectives). Because of the limitations in the study, some parts of the different levels of analysis suggested by Roche (2000) were excluded in this study. For example, in the dramatological dimension corresponding to "the potential use of particular events as occasions for particular symbolic political actions and communications" it was not possible to get a feed-back from some of the actors involved in the events such as players and spectators. Nevertheless, the symbolic meaning of the events for those actors responsible to organize the events concerned was analyzed by using in-depth field interviews. Accordingly, in the study, firstly the system of the events or games together with the implementation process are analyzed with a specific focus on the role of the local administrative institutions and other shareholders (private sector, non-governmental actors) in the process. This actually and partly corresponds to the contextual dimension of the multi-sport event analysis perspective.

Subsequently the extent of the impact expected on the city is revealed by focusing on the following general topics (given in the first column of Table 5). Summary tables were prepared by using the in-depth field research and interviews in order to evaluate the process of location selection for the venues, planning the investment according to decisions; and to evaluate whether these decisions were rational and effective. Additional topics covered in these tables can be given as below (given in the second column of Table 5). Considering these different levels of analysis and contexts, the research findings of in-depth field surveys and interviews about the sports events are listed in Table 13, Table 14 and Table 15 given in Appendix. 
Table 6. The investment made for $25^{\text {th }}$ Winter University Games in Erzurum 2011

\begin{tabular}{cll}
\hline \multicolumn{2}{c}{ Name of venues } & Location \\
\hline $\begin{array}{c}\text { Direct investments } \\
\text { I }\end{array}$ & Jumping Towers & City center \\
2 & Cemal Gürsel Stadium & Urban periphery center \\
3 & Hockey Hall & City center \\
4 & Ice Skating Hall & City center \\
\hline 5 & Curling Hall & City center \\
6 & Short Track Hall & City center \\
7 & Kandilli Ski Center & Urban fringe- city \\
8 & Palandöken Ski Center & City center \\
9 & Konakli Ski Center & Urban fringe- city \\
I0 & Olympic Village (3000 Student Dormitory Building Capacity) & City center \\
\hline II & Media/Press broadcasting center & City center \\
\hline Indirect investments & Transportation roads concerned with venues & Urban periphery-city center \\
\hline 13 & Basic urban infrastructure (sewer, telephone/internet lines, fiber optic cables... etc) & Urban periphery-city center \\
\hline 14 & The city renovation/restoration (cladding... etc) & City center \\
\hline
\end{tabular}

\section{I. Erzurum-20 I I World University Winter Games}

With University Winter Games (Universiade) held in Erzurum in 201 I, Turkey re-hosted a mega sports event years after the Mediterranean Games held in Izmir 197I. 20II World University Winter Games was the first winter games hosted in Turkey. The mascot of the games is a double headed eagle. Following this event, the idea of hosting similar events appeared in the agenda of the central government. Subsequently necessary legal steps were taken, and a core staff was formed for similar events, and training was provided.

Erzurum inhabitants regarded the 20II World University Winter Games as "the project that would save the city". Considering the dramatological dimension of the method of analysis used in this study, therefore there was a high expectation from the games in the city. Organizing committee made a serious preparation and presentation for the event. Inhabitants of both Erzurum and neighboring cities were motivated for the Games. In turn, this led to the creation of a driving power of the people behind the games.

A high quality technical infrastructure was created for winter tourism and sports in Erzurum via the investments made for the Games. The respective infrastructure covers 10 sports venues of which 8 are new and 2 are renovated. In addition to the construction of these venues, some of the roads in the city was re-asphalted and some urban parks were rehabilitated. For the Games, a curling hall, $2^{\text {nd }}$ biggest in Europe and I $^{\text {st }}$ one in Turkey, was constructed in Erzurum. Overall, the investment made for $25^{\text {th }}$ Winter University Games in Erzurum $201 \mathrm{I}$ is given in Table 6.

When the decisions concerning the location selection of the facilities is considered, it is observed that the distribution of sports venues in Erzurum presents a compact form thanks to the suitability of the topographic structure of the city. In the selection of locations for the venues, priority was given to the public lands with no allocation problems and venues were also located and allocated according to profiles of neighborhood units. For example, Kandilli Cross-Country Skiing\&Biathlon together with Konakli Alpine Ski Venues were built in a new development area, and Curling Arena located in Mecidiye neighborhood was built in the respective neighborhood unit by considering the intention to transform the area occupied by the squatters there. Overall, location selection decisions were in general consistent with the planning decisions and distribution of venues over urban space was more balanced.

Currently Kandili Ski Jump Towers and venues are being used relatively less frequently than other venues. Although rarely used by local people, it is highly possible that this venue could be used to train athletes performing those sports in Turkey in the future. As for Kandili and Konaklı Venues, these are the areas used for camping, and appearing in the agenda of long term developments.

Overall it is evident that the lack of technical infrastructure 
for winter sports have been overcome by new investments in Erzurum. Yet, in spite of re-asphalting of roads in the city and some landscape work, there was no investment in the public transport systems (such as metro, light rail) expected by the citizens in Erzurum within the framework of the Games. It is important to encourage projects increasing the use of the sports facilities constructed for the Games such as opening courses and supporting amateur clubs parallel to the efforts aiming at the employment of the facilities to host new international and national competitions. Overtime number of licensed athletes and coaches will increase and it is expected that sports facilities will be used with a high level of occupancy.

In terms of contribution of the event to the sports culture of the city, it is observed that new amateur sports clubs have been established parallel to the increase in the number of athletes in various branches of sports that was not widespread in Turkey such as curling and ice hockey. Nevertheless some problems were experienced in the organization of the $25^{\text {th }}$ Winter University Games in Erzurum such as conflict between local institutions and central institutions, problems in the allocation of sports venues, the shortage of specialized personnel, inexperience of staff in foreign languages, transportation problems and shortages in quality accommodation. Although small size and compact nature of the city eliminates the transportation problem, there is a transportation problem between other venues, especially Curling Area, even though they are located in the city center.

After the Games, the problems in transportation (connection to Curling Arena, Konakli Alpine Ski and Kandilli CrossCountry Skiing \& Biathlon Venues) and shortages in quality accommodation have continued parallel to the delays in the transfer of some of the venues to local bodies responsible for them. Olimpic village and medico-social building were handed over to the General Directorate of Higher Education Credit and Hostels Institution for the use of the University. The venues under responsibility of municipality and governorship were handed over to the institutions concerned, and all the other venues were transferred to Provincial Directorate of Youth and Sport.

Although it was expected that the Games would create an impetus for the economic development in the city, the organization of the event did not lead to a major increase in the revenues of the people in the city. Küçüktaş (2015: 87) argues that this stems from the lack of experience in the organizations of such kind of big sports events in Turkey:

Turkey hosting Winter University Games for the first time is inexperienced in benefiting from the potential of Olympic games in terms of economic development. For example, compared with the other organizations Erzurum Winter Uni- versity Games was not very successful in many issues such as revenues from television broadcasting, sponsorship, selling of tickets, marketing of souvenirs, fairs, organization of exhibitions, and etc.

After the Games, in terms of economic growth there was again no major increase in the revenues of the people in the city, which arises from the inadequacies in the planning of the activities for marketing of the city not only during but also after the Games. It is clear that the expectations from the Games in terms of local economic development stemming from the sports and winter tourism in Erzurum can only be met if the necessary precautions are taken in the marketing activities for the city. Nevertheless, it is important to remark that people thought the event had contributed positively to the city, and a serious infrastructure had been laid for winter sports in tourism sector.

The event has greatly contributed to the development of Erzurum's sports culture. With the venues acquired owing to winter Games, relatively less performed sports such as curling, ice skating, sledding, jump sports have gained more popularity in Erzurum and also in Turkey. Encouraging projects have been launched with the attempts of Provincial Directorate of Sports and the Governor in order to promote these sports. It is no accident that in Tourism Master Plan of Turkey targeting 2023 Erzurum is designated as one of the major destinations for "Winter Tourism" in the country (Tourism Strategy of Turkey-2023, Action Plan). In the respective plan, winter tourism and sports are supported in Erzurum with a vision of Erzurum as a "Sports City". In this way, the city is designated as the center of winter sports and tourism in Turkey. Erzurum is already one of the official camping centers declared by the Ministry of Youth and Sports in order to train skillful athletes. Parallel to this the city has started to host the winter sport camps triggering the development of sports economy in Erzurum. All these activities are actually parts of the efforts for the candidacy of Erzurum to host 2022 Winter Olympics. In sum, Erzurum has shown great success in becoming a winter sports city with these attempts.

\subsection{Trabzon-20I I European Youth Olympic Games}

The well planned promotion and advertisement activities for the organization of the Games led to the creation of a driving power of the people behind the games. A relatively rich technical infrastructure was created for the sportive activities all over Trabzon province thanks to the distribution of the events for the Games across the districts in the province in a balanced way. Within the scope of the Games a variety of sports facilities were created according to international standards. The respective facilities covers 15 sports venues of which 3 are new and 12 are renovated. The first hall for 
Table 7. The investment made for Trabzon 20II European Youth Olympic Games

\begin{tabular}{lll}
\hline & Name of venues & Location \\
\hline I & Hayri Gür Gym (7500 seats capacity) & Pelitli county \\
2 & Swimming Pool & City center \\
3 & Söğütlü Athletic Field & Söğütlü county \\
4 & Yomra Gymnastics Hall, & Yomra county \\
5 & Beşirli Tennis Complex & City center \\
6 & Olympic Village & City center \\
7 & M. Akif Ersoy Swimming Pool Surroundings Regulation & City center \\
8 & Yomra-Arsin-Araklı-Of-Çarşıbaşı-Vakfıkebir Gym Cooling and Ventilation Installations Making & Counties \\
9 & Arsin , Araklı, Of Sport Hall Surroundings Regulation & Counties \\
10 & Transportation roads concerned with venues & Urban periphery-city center \\
II & Basic urban infrastructure (sewer, telephone/internet lines, fiber optic cables... etc) & Urban periphery-city center \\
12 & The city renovation/restoration (cladding... etc) & City center
\end{tabular}

the branch of gymnastic in Turkey is constructed in Trabzon province within the framework of the Games.

Two factor was decisive in the selection process of the Games that would be held in Trabzon. The first was the political mechanism. Besides the central bureaucracy, the effectiveness of local bureaucracy also came to the fore. The desire to take a share from the event and pressure from local government caused an irregular distribution of venues across the towns. Secondly, the topography of Trabzon city was considered to a certain extent. However, lack of habitable lands and appropriate size for venues were important considerations. Yomra Gymnastics Hall, Hayri Gur Sports Hall and Sögütlü Athletic Track were built in towns instead of Trabzon city center where they would be more appropriately located. In addition, every gymnastic hall was almost renovated in Trabzon. The investment made for Trabzon 20 I I European Youth Olympic Games (EYOF) is given in Table 7.

The balanced distribution of the events across the towns was instrumental in the creation of a certain level of excitement among the people in the city. Also the selection of anchovy as the mascot of the Games was very sympathetic; it symbolized the culture of the city, and played an important role in the integration of the Games with the city. The mascot gained much popularity among the people. Combined with the familiarity of the people with sportive activities and the fact that city was also accustomed to such events owing to the organization of the Ist Black Sea Games in 2007 in the city, the organization of the Games became successful in the province.

It is observed that owing to the geographical limitations the venues constructed or renovated for the Games in Trabzon are distributed in a linear pattern along Of-Trabzon-Vakfıkebir axis of $98 \mathrm{~km}$ passing through the cities of Of, Araklı, Arsin, Yomra, Söğütlü, Çarşıbaşı and Vakfıkebir. In the selection of locations for the venues, priority was given to the public lands with no allocation problems and to the balanced distribution of the venues according to the districts as long as possible considering also their familiarity with different kinds of sportive activities. For example owing to the fact that the majority of the people actively playing tennis is living in Beşirli neighborhood, Tennis Complex for the Games was constructed in the respective neighborhood unit.

One of the most important problems experienced after the games was transportation between venues. Transportation problems between venues were actually the result of the pressure of the neighboring towns and lack of the appropriate space in Trabzon city center. Currently Yomra Gymnastic hall, Söğütlü Athletics Course and the Pelitli Hayri Gür Sports Hall have been rarely used and benefited only at the local level, due to their remote location. The gymnastic hall built in Trabzon is the first hall in Turkey constructed for the branch of gymnastic. However, despite the request for its being constructed in the city center it was built in Yomra due to local bureaucratic pressures. Built $17 \mathrm{~km}$ away from Yomra, it is rather far away from common use in terms of transportation. The same situation also applies to Pelitli Hayri Gür and Sögütlü athletics fields. Moreover the Olympic Games and the Press Centre Offices built in Trabzon were transformed into Youth Centers because they could not be used after the events.

Within the scope of the Games not only the technical infrastructure for the sportive activities in Trabzon is strengthened but also some of the roads in the province was re-asphalted and some urban parks were rehabilitated in order to create a vivid urban landscape for the Games. Unfortunately, paral- 
lel to Erzurum, there was no major investment in the public transport systems (such as the construction of a metro or light rail system) which was actually expected by the citizens in Trabzon within the framework of the Games.

After the Games, parallel to Erzurum, Olimpic village and medico-social building were handed over to the General Directorate of Higher Education Credit and Hostels Institution for the use of the University. The venues under responsibility of municipality and governorship were handed over to the institutions concerned, and all the other venues were transferred to Provincial Directorate of Youth and Sport.

Organization of European Youth Olympic Games in Trabzon was not without problems. Both before and during the Games many problems were experienced in the organization of the Games such as the allocation of the land for the construction of the facilities required for the Games, the shortage of qualified staff for the organization of the Games, the inexperience of the staff both in foreign languages and in the organization of similar events, conflict and competition between local institutions, transportation problems and shortages in quality accommodation. The problems experienced after the Games was mostly related to the delays in the transfer of some of the venues to local bodies responsible for them, the transportation problems (weak connection between Pelitli Hayri Gür Sports Hall, Yomra Gymnastic hall, Söğütlü Athletics Course) and shortages in quality accommodation. Unfortunately, sports facilities could not also be used with high level of occupancy after the Games due to the failure in the attraction of the local people to the facilities concerned.

Nevertheless, the projects launched by Provincial Directorate of Sports and Youth to encourage the use of venues such as opening courses for various types of sports, hosting international and national competitions, the increase in the number of amateur clubs and licensed athletes together with coaches, the designation of Trabzon as one of the official centers for sports camps by the Ministry of Sports and Youth to train skillful athletes, and subsequently hosting the camps of the clubs for summer sports in Turkey have led to an increase the use of the sports facilities constructed for the Games.

\subsection{Mersin- 17. Mediterranean Games}

The Games had first been given to the city of Volos in Greece; however, the Committee switched the host to Mersin in 2011 because of the economic crisis going on in Greece. Thus, the event that is usually organized within a period of 6 years including also the candidacy period had to be organized in Mersin within only 18 months. However, time constraints of the event have created some problems for the subsequent use of the venues. So Turkey had a very limited time left for the preparation process, and had to make some urgent decisions. The selection of the venues had been determined by the officers under the direction of Governor of Mersin. Due to time constraints, only lands that are publicly owned were preferred. Most of the venues were constructed in these lands located generally within Yenişehir Municipality.

Thanks to both the priority assigned to the public lands with no allocation problem in the selection of locations for the construction of the sport facilities and the fact that the respective lands were agglomerated along certain routes in Toroslar and Yenişehir districts, a linear pattern of dispersion is observed in the distribution of the venues in the city. As a result, a rich technical infrastructure for different sports was established within the reach of the metropolitan area. Within the scope of the Games, there was a total of 54 venues of which II are new and 43 are renovated in the provinces of Mersin and Adana. The second special hall for gymnastics in Turkey was built in Mersin within the framework of the Games. The investment made for 17. Mediterranean Games held in Mersin 2013 is given in Table 8.

In general, a widespread and linear distribution can be observed in the distribution of the venues along an axis of 200 $\mathrm{km}$ passing through the cities of Adana, Mersin, Tarsus and Erdemli. Yenişehir and Toroslar (Northern Mersin), the city's new residential districts, were selected for the construction of new sports facilities instead of other districts in Mersin in order to promote development in this part of the metropolitan area. Accordingly, Olympic Village, Mersin Stadium, Servet Tazegül Arena, Mersin Gymnastics Hall, Mersin Tennis Complex, Nevin Yanıt Athletics Complex and Mersin Olympic Swimming Pool were built in this region. No new venues were constructed within the boundaries of Akdeniz District which is the historical center of the city, and the Mezitli District in the west of Mersin City except for the renewed ones.

A balanced distribution of venues for Mersin Games was not possible owing to the limitations in the availability of public lands and rapid decision-making process. This led to unequal distribution of venues for public use. As these venues were not also easily accessible to the public in general, concentration of them in Northern Mersin creates an inequality in the use of the facilities concerned. There are no qualified and continuous high-capacity public transport (such as a light rail system or metro, subway) to the new sports facilities that were mainly built along the $3^{\text {rd }}$ belt highway in Northern Mersin. Therefore, additional public transportation is actually required in addition to the minibuses currently operational along the respective route.

However, the city has gained an important infrastructure with the Games. First of all, a brand new expressway (a new link 
Table 8. The investment made for $X V \|^{\text {th }}$ Mediterranean Games held in Mersin 2013

\begin{tabular}{|c|c|c|}
\hline \multicolumn{2}{|c|}{ Name of venues } & Location \\
\hline \multicolumn{3}{|c|}{ Direct investments } \\
\hline I & Nevin Yanıt Athletics Complex & Urban periphery-toroslar city \\
\hline 2 & Erdemli Shooting Range & Urban fringe-Erdemli city \\
\hline 3 & Tennis Complex & Urban periphery-Yenişehir \\
\hline 4 & Mersin Stadium & Urban Fringe-Yenişehir \\
\hline 5 & Bocce Hall & Urban periphery-Toroslar, \\
\hline 6 & Gymnastic hall & Urban periphery-Yenişehir \\
\hline 7 & Olympic Swimming Poll & Urban periphery-Yenişehir \\
\hline 8 & Servet Tazegül Sport Hall & Urban periphery-Yenişehir \\
\hline 9 & Sport Hall (500 person) & Urban periphery-Toroslar \\
\hline 10 & Sport Hall (1000 person) & Urban periphery-Toroslar \\
\hline II & Olympic Village & Urban periphery-Yenişehir \\
\hline \multicolumn{3}{|c|}{ Indirect investments } \\
\hline 12 & The illumination of Tevfik Gur Stadium & Center-Akdeniz \\
\hline 13 & Edip Buran Sports Hall Renovation & Center-Akdeniz \\
\hline 14 & Mezitli Sports Hall Renovation & Center-Mezitli \\
\hline 15 & Erdemli Sports Hall Renovation & Center-Erdemli \\
\hline 16 & Tarsus Sports Hall Renovation & Center-Tarsus \\
\hline 17 & Seyfi Alanya Sports Hall Renovation & Center-Yenişehir \\
\hline 18 & Zone 7 Sports Hall Renovation & Center-Toroslar \\
\hline 19 & Transportation roads concerned with venues & Urban periphery-center \\
\hline 20 & Basic urban infrastructure (sewer, telephone/internet lines, fiber optic cables... etc) & Urban periphery-center \\
\hline 21 & The city renovation/restoration (cladding... etc) & Urban periphery-center \\
\hline
\end{tabular}

called as 34. Street) has been built between Yenişehir Fair Area and new Stadium connected to the highway between Mersin and Adana. Many roads have also been made or renovated. In this scope, a total of $25 \mathrm{~km}$ road has been constructed for the Games. Refuges along the boulevards have also been fixed thanks to the Games. A number of improvements including repairing current road infrastructure, landscaping, facade cladding and image editing was done. However, parallel to the experience in Erzurum and Trabzon, the expectations for a new public transport system (such as light rail or metro) in the city was not met.

The Olympic village was handed over to the General Directorate of Higher Education Credit and Hostels Institution for the use of the University. As it is the case of other sports events in Erzurum and Trabzon, the venues under responsibility of municipality and governorship were handed over to the institutions concerned, and all the other venues were transferred to Provincial Directorate of Youth and Sport.

The fact that the whole organization was carried out in a very limited time period led to some inefficiencies in the planning of the games. In turn, this caused some problems in the organization of the $17^{\text {th }}$ Mediterranean Games. Prior to and during the games, many problems were experienced such as conflict between local institutions and central institutions, space allocation problems, transportation problems, shortage of quality accommodation, accommodation shortages, the heavy pressure on the local officials to complete the construction of facilities timely, insufficient promotion of the Games and accreditation problems. Problems encountered after the games are the qualified accommodation shortage (bed capacity), weak transportation connection between newly built venues in Northern Mersin and the rest of the city, and the delays in the transfer of some of the venues to local bodies responsible for them. Parallel to Erzurum and Trabzon, unfortunately, sports facilities could not also be used with a high level of occupancy after the Games owing to the failure in the attraction of the local people to the facilities concerned. Another problems is associated with the fact that the facilities built is not adequate for the training of amateur clubs in terms of their capacity. 
The Mediterranean Games held in Mersin in 2013 was an important tool for the promotion of Mersin (Doğan, 20I2). Also the selection of mascot was very successful. However, due to the limited time it failed to perform adequate promotion and marketing activities. Lack of promotion hampered the city's active contribution to the Games. Involvement of the citizens in the organization of the Games was late and the level of excitement for the games was relatively low compared with the other games in Erzurum and Trabzon. Nevertheless, in contrast to the other Games in Erzurum and Trabzon, in Mersin it was possible to recruit more experienced staff for the organization of the Games thanks to the availability of qualified staff owing to the experience gained in previous organizations.

Overall, the games greatly contributed to the development of sports culture in Mersin. It led to diversification of the sports branches (including Gymnastics) in the city. Encouraging projects have been launched with the attempts of Provincial Directorate of Youth and Sport in order to promote these sports. Parallel to Trabzon it is observed that overtime an increase occurred in the use of the sports facilities constructed for the Games in Mersin thanks to new courses for various types of sports, hosting international and national competitions, the increase in the number of amateur clubs and licensed athletes together with coaches, the designation of Mersin as one of the official centers for sports camps by the Ministry of Sports and Youth to train skillful athletes, and subsequently hosting the camps of the clubs for summer sports in Turkey.

\subsection{Findings and problems}

For all the Games, venues were built according to international standards in the cities concerned. Some of them, such as Yomra Gymnastics Halls in Trabzon and Mersin, have been constructed for the first time in Turkey. Likewise the curling, biathlon, gymnastics halls have been the first facilities of their kind in Turkey, solely built for these sports. Before the games, actually we observe some successful performances regarding the branches of sports for which some infrastructure is currently available in the respective cities. Curling as a branch of winter sports has become more popular since 2011 with Universiade Erzurum. Previously curling was organized under Turkish Ice Skating Federation. After the Games, a separate federation was established for curling. As a result of this, many professional and amateur clubs have been established in Turkey for curling after the Games particularly in Erzurum and also in other provinces (Curlingl). For example, after the Federation of Ice Skating began its first Curling performances in Turkey in 2009, Lady Curling Team became the second winner in European Curling Championships organized in Scotland in 2010. It is known that two players of this team are continuing their training in Curling Hall in Erzurum (Curling2). Likewise Mans' National Curling Teams become champion in 2012 in Debrecen. Three players of this team were athletes trained in Curling Hall in Erzurum (Curling3). Another example is bocce in Mersin. Until 2013 year there was no athletes in bocce. But after the Mediterranean Games, two athletes in 2014 and 2015, four athletes in 2016 were selected for Turkish National Bocce Teams. Parallel to this, there was an important increase in the number of licensed and active athletes in Erzurum, Trabzon and Mersin between 2008 and 2015 (see Table 9).

In Erzurum the number of licensed athletes has increased more than twice from 21,778 in 2008 to 46,486 in 2015, and the number of active athletes has increased almost thrice from 5.738 in 2008 to 16.423 in 2015 . Similarly, in Trabzon the number of licensed athletes has increased more than twice from I5.004 in 2008 to 35.067 in 20I5, and the number of active athletes has increased almost twice from 3.112 in 2008 to 6.027 in 2012. Nevertheless it decreased to 4.626 in 2015 . In Mersin the number of both licensed athletes and active athletes has increased almost twice respectively from 42,973 in 2008 to 75,990 in 2015, and from 4,510 in 2008 to 8,979 in 2014 . Yet, the number of active athletes decreased to 7.246 in 2015 . What is most striking in these observations is the fact that both in Erzurum and Trabzon the number of active athletes increased almost twice in the year subsequent to the Games.

These cities have also been declared by The Youth and Sport Ministry as the camping centers in order to train skillful athletes. Federation attracted national and international events to the cities, and venues acquired through these events began to be used to host them. In the future, these venues will take the lead to promote the branches such as curling, ice hockey, Nordic skiing, Skiing, Sled, lce skating, sky jumping and bocce (see some of them statistics Table 10). The number of these athletes in these three cities is given in Table 10. In addition to this, new amateur clubs have also been formed in the respective cities (see Table II).

Another obstacle to an efficient use of Olympic heritage is the lack of training for some of the venues. Large scale venues had been planned for niche performances such as competitions. Following sports events held in the cities concerned, a lot of new amateur clubs have been formed (see Table II); however, these clubs didn't have training facilities and means, and their current training fields have been far from the city centers. Likewise, the title transfers of these venues, originally in the ownership of the department of Youth and Sport Ministry, takes too much time. This situation delays the public use of the venues; depriving the venues of necessary care and maintenance. 
Table 9. The number of athletes in Erzurum, Trabzon and Mersin cities between the years 2008-20I5

\begin{tabular}{|c|c|c|c|c|c|c|c|}
\hline Province & Year & Licensed women & Licensed men & Total licensed & Woman active & Man active & Active total \\
\hline \multirow[t]{8}{*}{ Erzurum } & 2008 & 3.822 & 17.956 & 21.778 & 791 & 4.947 & 5.738 \\
\hline & 2009 & 4.587 & 19.294 & $23.88 I$ & 1.321 & 4.545 & 5.866 \\
\hline & 2010 & 5.236 & 20.758 & 25.994 & 1.053 & 4.050 & 5.103 \\
\hline & 2011 & 5.903 & 22.639 & 28.542 & 1.120 & 5.079 & 6.199 \\
\hline & 2012 & 7.773 & 28.053 & 35.826 & 3.176 & 10.275 & $|3.45|$ \\
\hline & 2013 & 9.571 & 30.684 & 40.255 & 4.714 & 12.048 & 16.762 \\
\hline & 2014 & 10.624 & 33.009 & 43.633 & 4.511 & 11.633 & 16.144 \\
\hline & 2015 & II.638 & 34.848 & 46.486 & 4.649 & I I.774 & 16.423 \\
\hline \multirow[t]{8}{*}{ Trabzon } & 2008 & 4.020 & 10.984 & I 5.004 & 937 & 2.175 & 3.112 \\
\hline & 2009 & 4.472 & 11.905 & 16.377 & 1.149 & 2.618 & 3.767 \\
\hline & 2010 & 5.001 & 13.124 & 18.125 & 1.050 & 2.327 & 3.377 \\
\hline & 2011 & 5.504 & 14.409 & 19.913 & 947 & 2.149 & 3.096 \\
\hline & 2012 & 7.738 & 17.907 & 25.645 & 2.235 & 3.792 & 6.027 \\
\hline & 2013 & 9.411 & 20.456 & 29.867 & 2.034 & 3.300 & 5.334 \\
\hline & 2014 & 10.376 & 22.608 & 32.984 & 1.875 & 3.504 & 5.379 \\
\hline & 2015 & II.008 & 24.059 & 35.067 & 1.422 & 3.204 & 4.626 \\
\hline \multirow[t]{8}{*}{ Mersin } & 2008 & 13.516 & 29.457 & 42.973 & 1.348 & 3.162 & 4.510 \\
\hline & 2009 & $\mid 4.637$ & 31.919 & 46.556 & 1.880 & 4.187 & 6.067 \\
\hline & 2010 & | 4.286 & $30.45 I$ & 44.737 & 1.401 & 3.518 & 4.919 \\
\hline & 2011 & 15.963 & 35.737 & 51.700 & 1.447 & 3.769 & 5.216 \\
\hline & 2012 & $|8.01|$ & 39.999 & 58.010 & 2.091 & $4.51 I$ & 6.602 \\
\hline & 2013 & 20.374 & 44.001 & 64.375 & 2.647 & 4.768 & 7.415 \\
\hline & 2014 & 23.267 & 48.511 & 71.778 & 3.456 & 5.523 & 8.979 \\
\hline & 2015 & 24.963 & 51.027 & 75.990 & 2.894 & 4.352 & 7.246 \\
\hline
\end{tabular}

Source: The Youth and Sport Directorates of Mersin Province (21.11.2016).

Another problem is the development of sport habits among the population for the use of these facilities. The Youth and Sport Directorates of Provinces have been putting great efforts to develop these habits together with the other institutions (Youth and Sports Ministry, Municipalities, Religious Provincial Directorate) in the cities. Together with the campaigns and projects, they aim to develop a certain sport culture in the cities concerned, so the use of the venues has been increasing in this way. The common goal of these institutions is to prevent these facilities and investments from turning into white elephants, so that they can be used both at the city and country levels. In this process the following factors are important:

I. To consider the city's original structure,

2. To make decision for rational selection of location,

3. To reveal their contribution to urban spatial, economic, and social structure,

4. To consider their impact on urban culture and social-cultural life,
5. To plan the use of the facilities following the events,

6. To aim at a holistic cultural environment,

7. To prevent possible damage these events would have on the natural environment.

Large-scale sporting events can offer different perspectives on economic development of the city, if they are properly implemented. It is still possible to observe the positive results of the Games in the cities of Erzurum, Trabzon and Mersin hosting the games concerned in terms of urban development of the respective cities (see Table 12). The development of sports tourism would create a new opportunity for the reconstruction of the economic structure of these cities. Given their unique nature, Erzurum has a potentially favorable climate for the development of winter sports, and Trabzon has appropriate social structure and character for the development of sports events. Again, Mersin is a city that has produced talented athletes having won many medals in various categories. Currently, these three cities have ready facilities 
Table I0. The number of licensed athletes and sports federations between the years 2007-2014

\begin{tabular}{lcccccccc}
\hline Federations & $\mathbf{2 0 0 7}$ & $\mathbf{2 0 0 8}$ & $\mathbf{2 0 0 9}$ & $\mathbf{2 0 1 0}$ & $\mathbf{2 0 1 1}$ & $\mathbf{2 0 1 2}$ & $\mathbf{2 0 1 3}$ & $\mathbf{2 0 1 4}$ \\
\hline Ice hockey & $\mathbf{2 . 4 6 7}$ & 2.803 & 3.664 & 3.913 & $\mathbf{4 . 6 6 4}$ & 5.518 & 6.099 & $\mathbf{6 . 2 8 9}$ \\
Ice skating & $\mathbf{6 8 2}$ & 885 & 1.181 & 1.465 & $\mathbf{2 . 1 7 7}$ & 2.729 & 3.304 & $\mathbf{3 . 6 0 4}$ \\
Gymnastics & $\mathbf{1 4 . 0 7 I}$ & 13.950 & 14.505 & 14.441 & $\mathbf{1 5 . 3 2 9}$ & 18.005 & 25.990 & $\mathbf{3 5 . 4 2 5}$ \\
Skiing & $\mathbf{1 5 . 9 9 5}$ & 17.064 & 18.763 & 20.437 & $\mathbf{2 2 . 0 8 5}$ & 23.566 & 25.559 & $\mathbf{2 6 . 7 9 3}$ \\
Sled & - & - & - & 104 & $\mathbf{1 2 2}$ & 201 & 293 & $\mathbf{3 4 2}$ \\
\hline
\end{tabular}

Source: Turkish Statistical Institute (TÜiK), http://www.turkstat.gov.tr/, (0I.II.20I6)

Table II.The number of clubs in Erzurum, Trabzon and Mersin cities between the years 2005-20I5

\begin{tabular}{|c|c|c|c|c|c|c|c|}
\hline Province & Year & Military & Establishment & Specialization & School & Sports club & Total \\
\hline \multirow[t]{4}{*}{ Erzurum } & 2005 & 0 & 0 & 25 & 2 & 34 & 61 \\
\hline & 2010 & 0 & 22 & 25 & 6 & 49 & 102 \\
\hline & 2011 & 0 & 22 & 26 & 5 & 63 & 116 \\
\hline & 2015 & 0 & 23 & 3 & 9 & 125 & 160 \\
\hline \multirow[t]{4}{*}{ Trabzon } & 2005 & 0 & 9 & 15 & 1 & 114 & 139 \\
\hline & 2010 & 0 & 9 & 9 & 4 & 158 & 180 \\
\hline & 2011 & 0 & 8 & 9 & 5 & 159 & $|8|$ \\
\hline & 2015 & 0 & 9 & 10 & 2 & 194 & 215 \\
\hline \multirow[t]{4}{*}{ Mersin } & 2005 & 0 & 28 & 11 & 10 & 92 & $14 \mid$ \\
\hline & 2010 & 0 & 26 & 12 & 16 & 160 & 214 \\
\hline & 2013 & 0 & 37 & 12 & 30 & 217 & 296 \\
\hline & 2015 & 0 & 31 & I I & 31 & 269 & 342 \\
\hline
\end{tabular}

Source: The Youth and Sport Directorates of Mersin Province (21.11.2016).

that can contribute to urban development through sports with their different advantages.

The cities of Erzurum, Trabzon and Mersin have attracted huge investments in the establishment of sports facilities and infrastructure for the first time in their history. These investments are expected to contribute to urban development policy so as to use them in the long-term urban policy. As such, these events proved to be ineffective in solving the deep-rooted problems of the cities. For example, long needed light rail transport systems expected in Erzurum, Trabzon and Mersin have not been realized for many years.

The concentration of the facilities built for the $17^{\text {th }}$ Mediterranean Games in Northern Mersin has played an important role in the increase of land and real estate prices in this region. Nevertheless, these events have become instruments for urban transformation projects. They are considered to be a good opportunity for realizing and accelerating large-scale urban development and transformation projects planned for the long-term. For example, the selection of Curling hall in Erzurum was a decision taken to transform the neighborhood, and the decision was one expected to facilitate the transformation in this region where construction industry was in a bad state, and the rate of crime was high.

The selection of the location of facilities is an important criterion for their use and accessibility. In this respect, macroform of the city plays an important role. For example, although Erzurum presents a compact form, Trabzon and Mersin are characterized by liner conglomerations. However, the use of public lands in order to reduce the costs caused much controversy; consequently instead of a rational selection of venues, existing distribution of public lands has been decisive in the selection of venues, and consequently these caused problems in transportation between venues. Currently it is quite necessary to reinforce the infrastructure that is providing access to these venues.

There was an undeniably serious pressure from the central 
Table 12. Erzurum, Trabzon and Mersin comparison

\begin{tabular}{|c|c|c|c|}
\hline & Trabzon & Erzurum & Mersin \\
\hline Difficulties in access to facility & + & $+/-$ & + \\
\hline The usage of the facility & $+/-$ & + & $+/-$ \\
\hline To evaluate the process location selection decisions (whether these were rational and effective) & $+/-$ & + & - \\
\hline $\begin{array}{l}\text { Whether infrastructure problems were fixed and the extent to which the expectations for } \\
\text { quality of life were met }\end{array}$ & - & - & - \\
\hline Whether subsequent use of venues were planned beforehand & - & - & - \\
\hline The impact on local development & $-\left.\right|^{*}$ & + & $-1 *$ \\
\hline The contribution of the process to the sport culture of the cities & + & + & + \\
\hline The impact on urban policies & $+/-$ & + & $+/-$ \\
\hline+ & There is & & \\
\hline- & There isn't & & \\
\hline$+/-$ & Both there & & \\
\hline$-1 *$ & Possible & & \\
\hline
\end{tabular}

government about the use of the venues in Erzurum, Trabzon and Mersin. The pressure aimed to promote the use of venues in an attempt to show that all these have not been built in vain. In large-scale international events, it's the municipalities that host these events. However, in Turkey, it is the Department of Youth and Sports that implement the events. This may have advantages regarding the budget transfer; nevertheless, this may also create some conflicts between central government and local authorities even though they belong to the same political party. In the case of these cities, the intervention of the government in the planning delayed the decision process. In this respect, the central authority always caused delays in the decision making process with its intervention.

These examples show that the use of venues following the event must be carefully planned. However, we found that in all these three cities no planning had been made considering a possible future use. For example, if venues will not be used after events, they should have been built with temporary portable techniques, or if for permanently, they should have been designed in flexible ways. Olympics towns constructed in the scope of Games have been transferred to Yurtkur (Government Directorate responsible for student dormitories for public).

\section{Conclusion}

Nowadays, there is a competition between cities under neoliberal pressures. One of the areas which is experiencing this competition is mega-events. Parallel to these, a new approach has appeared in local and regional economic development. This approach aims at branding, re-presentation, introduction of cities to the global networks so as to benefit from the glob- al capital as much as possible. In this context, sports, culture and arts are used together as a tool to capture the economic benefits. For example; London 2012 Cultural Olympiad in the UK was held in conjunction with the London 2012 Olympics and almost kept in the forefront as a cultural event. Thus, more attention was drawn to the Olympics, with enriching leisure activities provided to the guests. As a result of this, cultural activities contributed to the marketing of the city.

In Turkey, the international sports Games (Erzurum, Trabzon ve Mersin) organized in recent years have been important tools in the process that may lead to mega-events such as a possible Olympic nomination. With these events, our cities have had considerable experience in the organization of mega-events at local and national levels, competing with the other world cities for mega events.

Already equipped with strong sports infrastructure, other countries that host these type of events carry out these events with a relatively small budget. Owing to the lack of similar sporting infrastructure in our cities, events have been organized with large budgets in Turkey. Also there is an ongoing uncertainty on how to use these facilities in our cities after the events. In order to prevent them from turning into White Elephants, all facilities and infrastructure should be well planned. Additionally, a minimum level of these kinds of sports infrastructure should be available in all cities to ensure equality of opportunity for each citizen in the country.

When deciding on site selection for facilities, important factors such as transportation should be considered. There isn't an effective transportation network in the cities hosting the recent sports games in Turkey for the interconnection be- 
tween the facilities required in the games. For the efficient use of facilities, public transport routes should actually be reorganized. Currently, the distance between the facilities is a source of problem. Particularly, the facilities designed for specific branches such as gymnastics have to be located centrally for efficient use. The gymnastic facility constructed in Yomra District in Trabzon event is a good example for wrong location selection. The facility built in the city center or closer to the center would ensure an easy access and lead to the increasing use of the facility.

With the aid of the Games, relatively sustainable sporting infrastructure has been built in Erzurum, Mersin and Trabzon. Another important point is to make the sporting facilities permanent in social structure so as to transform the city into a sports town. However, this requires a long-term planning achieved parallel to the right policies. Especially the interests of school-age children should be taken into consideration, and training of athletes in various fields and the establishment of sport clubs should be encouraged. These considerations will be critically important in the development of a sports culture as a habit of life in the city. However, for the development of sports culture in the city, as well as the large facilities, sports venues should be built in a planned way.

After the Games Erzurum, Mersin and Trabzon regularly host national and international competitions. However, this situation does not cause great excitement in these cities. Yet, organization of specific games under the name of the cities concerned (such as Trabzon Marathon and Mersin Marathon) can make a contribution to the spreading of the various branches of sports currently less popular in Turkey. In a similar fashion, again, each year City Games (such as Erzurum Winter Games, Trabzon Games and Mersin Summer Games) can be organized in these cities. These games can be arranged in the form of a sports festival, where both the national and local athletes will compete together.

Mega-events are also opportunities for the social and cultural improvement in the city. The development of sports culture is said to go hand in hand with the development of urban culture. When sport is considered as a component of urban culture, it should be intertwined with the city's other cultural elements there, and there has to be a complementary structure that feeds them. Thus, in order to develop sports culture, building appropriate infrastructure and facilities will not be enough alone. Therefore we need to have a holistic perspective encompassing culture, art and sports within the urban cultural policy.

Somehow, large-scale investments initiate the process of restructuring and redefining of cities in a certain way. Megaevents that will be a good starting point for the solution of physical, economic and social-cultural problems of our cities should be planned by taking long-term development policies of cities into account and they should also be integrated with urban policies. Only in this way, the existing chronic problems can be solved more properly.

The multi-sport events held in our country have had certain impacts on urbanization. While some parts of these events were carried out with the projects prepared within the holistic framework of a plan and policy, others were performed with the short-term projects developed without a plan. The case studies show that if mega-events are to be used as an investment tool, they should be handled in a holistic framework and have to be well planned for that city. By focusing on the examples of Trabzon, Erzurum and Mersin, in this paper it is shown that the Turkish experience in this area has been gradually increasing, albeit it is not mature enough. A government and management strategy that takes local hidden forces into account enables the correct and rational way of creation of initiatives for the local development.

In sum, the contribution of the mega-events should be questioned. How can they contribute to the unresolved issues of the city? To what extent can they eliminate the lack of infrastructure in the city? In which way can they meet the expectations such as improving the quality of life? These questions must be answered by considering the size of budgets spent on the events and the ongoing economic crisis in the world. Also, a detailed plan for subsequent use of these venues has to be prepared, following the sportive, cultural and artistic events. In order to prevent them from transforming into White Elephants as dormant investments, development plans, strategies and policies of these events should be prepared before the events concerned. The basic pursuit of this paper is formulated by taking the above questions and considerations into account. The future studies on the subject matter can focus on other issues such as political power relations behind these events and re-evaluation of the general contribution of the investments made for the Games in the local economic and spatial development of the cities concerned after a predefined time period required for the realization of some expectations from the respective games. 


\section{REFERENCES}

Coaffee, J. (2008) 'Sport, Culture and the Modern State: Emerging Themes in Stimulating Urban Regeneration in the UK' in International Journal of Cultural Policy, Vol. 14, No. 4, pp. 377-397, Routledge: London and New York

Curling1, Available at http://www.haberler.com/turkiye-de-40-kent-curlingile- tanisacak-8714052-haberi/., (accessed 16.10.2016).

Curling2, Available at http://www.dunya.com/curling-bayan-milli-takimi,avrupa-ikincisi-oldu-101433h., (accessed 07.11.2013).

Curling3, Available at http://www.buzpateni.org.tr/haber-750-curling-millitakimimiz-altin-madalya-nin-sahibi.html, (accessed 07.10.2013).

Devecioğlu, S., (2005) “Türkiyéde Spor Sektörü Stratejilerinin Geliştirilmesi” Verimlilik Dergisi, 2005/2, pp. 117-134. Available at http://perweb.firat. edu.tr/personel/yayin lar/fua_9/9_31139. pdf. (accessed 07.10.2013).

Doğan, A. E. (2012) Akdeniz Oyunları: Mersin İçin Kaçırılan Fırsat mı Oluyor? Oda, Eylül 2012, Sayı 4, Mimarlar Odası Mersin Şubesi, Available at http://www.mersinmimod.org.tr/katalog/Oda-Dergisi\%20-04.pdf (accessed 07.07.2015)

Dündar, G. Ş., (2010) “Unvan Peșindeki Kentler: Mega Projeler ve Mega Etkinlikler Üzerinden Bir Bakış" Mimarlık Dergisi, 2010/353, pp. 53-58.

Edizel, Ö. (2014) Mega-Events as a Catalyst for Place-Marketing: Exploring Izmir EXPO 2015 Candidacy and Istanbul ECoC 2010, Regions 295, Autumn 2014. Available at http://www.tandfonline.com/doi/abs/10.10 80/13673882.2014.11006052 (accessed 07.06.2015).

Erten, S., (2005) “Büyük Ölçekli Kentsel Projeler ve Olimpiyat Oyunları: Atina 2004 Olimpiyatlar1 Deneyimi", Planlama Dergisi, 2005/2, pp. 45-52.

Erten, S., (2012) “Olimpiyat Kentleri ve Fiziksel Altyapı İnşasının Tarihçesi”, TMMOB Mimarlar Odası Dergisi, 2012/4, pp. 17-21.

Erzurum2011, Available at http://www.erzurum2011.gov.tr/anasayfa 2013, (accessed 06.10. 2015).

Essex S. and Chalkley, B., (2004), Mega-Sporting Events in Urban and Regional Policy: A History of the Winter Olympics, in "Planning Perspectives", Vol.19, No. 2, pp.201-232. Available at http://www.tandfonline. com/doi/abs/10.1080/0266543042000192475 (accessed 06.10. 2015).

Gratton, C., Shibli, S. and Coleman, R. (2005), 'Sport and Economic Regeneration in Cities' in Journal of Urban Studies, Vol. 42, Nos. 5/6, May, pp.985-999, Routledge: New York and London. Available at http://usj. sagepub.com/content/42/5-6/985.abstract (accessed 06.10.2015).

Hughson, J. (2004) 'Sport in the 'City of Culture' The Cultural Policy Connection' in International Journal of Cultural Policy, Vol. 10, No. 3, pp. 319-339, Routledge: London and New York.

Karaca, S. (2012) “Kültür Eksenli Kentsel Gelișim ve Kültürel Planlama Yaklaşımı” Yüksek Lisans Tezi, Mersin Üniversitesi Fen Bilimleri Enstitüsü.

Küçüktaş, R. (2015), “Büyük Ölçekli Etkinliklerin Ev Sahibi Ülkelere ve Kentlere Olan Etkileri” Uzmanlık Tezi, Available at http://www.kalkinma.gov.tr/Lists/Uzmanlk \%20Tezleri/Attachments/395/Büyük\%20 Ölçekli\%20Etkinliklerin\%20Ev\%20Sahibi\%20Ülkelere\%20ve\%20 Kentlere\%20Olan\%20Etkileri.pdf, (accessed 07.10.2015).

Mersin2013, XVII Mediterranean Games (XVII Akdeniz Oyunlar1), Available at http://www.mersin2013.gov.tr/, (accessed 05.10.2015).

Müller, M., (2015) The Mega-Event Syndrome: Why So Much Goes Wrong in Mega-Event Planning and What to Do About It, Journal of the American Planning Association, 81:1, 6-17, DOI: 10.1080/01944363.2015.1038292, Available at http://www.tandfonline.com/loi/rjpa20, (accessed 05.11.2016).

Penpecioğlu, M. (2013) “Urban Development Projects and the Construction of Neoliberal Urban Hegemony”, METU JFA, 30: 1, 165-189.

Roche, M. (2000) Mega-Events and Modernity: Olympics and Expos in The Growth of Global Culture. Routledge, London.

Silk, M. \& Amis J. (2005) Sport Tourism, Cityscapes and Cultural Politics, Sport in Society: Cultures, Commerce, Media, Politics, 8:2, 280-301. Available at http://www. tandfonline.com/doi/pdf/10.1080/09654310903497702, (accessed 17.09.2014).

Smith, A. (2010) The Development of "Sports-City" Zones and Their Potential Value as Tourism Resources for Urban Areas, European Planning Studies 18(3), 385-410. Available at, http://www.tandfonline.com/doi/ abs/10.1080/09654310903497702, (accessed 07.11.2013).

Smith, A. (2012) Events and Urban Regeneration: The Strategic Use of Events to Revitalize Cities, Routledge, pp.64-100, London, UK.

SPP, (State Personnel Presidency) First Five-Year Development Plan (19631967), Available at http://www. dpt.gov.tr/, (accessed 07.10.2013).

Özdan, V. (2013) “Türkiyénin Olimpiyat Macerası ve İstanbul'un Adaylığ1 Hakkında Son Söz", Available at, http://www.arkitera.com/haber/in$\mathrm{dex} /$ detay/turkiye-nin-olimpiyat -macerasi -ve- İstanbul-un-adayligihakkinda-son-soz/17089, (accessed 07.10.2013).

Özdemir, D. (2005) “Kent Merkezinde Kültür Eksenli Bir Dönüşüm Projesi: Temple Bar,Dublin", Arredamento Mimarlık, sayı: 2005/03, 98-105 s.,

Thefreedictionary, "White Elephants" Available at (http://www.thefreedictionary.com/ White+elephants, (accessed 03.11.2015).

Trabzon2011, European Youth Olympic Festival-2011, Available at

http://www.trabzon2011.gov.tr (accessed 10.11.2015).

Tourism Strategy of Turkey-2023, Action Plan 2007-2023,

(https://www.kultur.gov.tr/Eklenti/43537,turkeytourismstrategy2023 df.(accessed 03.10.2015).

Zukin, S. (2000) The Cultures of Cities, Black Well, Massachusetts. 


\section{Appendix}

Table I3. Erzurum, Trabzon and Mersin field research-I

\begin{tabular}{|c|c|c|c|c|}
\hline & & Erzurum & Trabzon & Mersin \\
\hline & & $\begin{array}{l}\text { Adoption of the Games by the } \\
\text { inhabitants. }\end{array}$ & $\begin{array}{l}\text { Adoption of the Games by the } \\
\text { inhabitants. }\end{array}$ & $\begin{array}{l}\text { Not adoption of the Games by the } \\
\text { inhabitants. }\end{array}$ \\
\hline & & $\begin{array}{l}\text { A serious promotion campaign } \\
\text { High expectations in the city, }\end{array}$ & A serious promotion campaign & $\begin{array}{l}\text { Insufficient promotion efforts due to } \\
\text { time constraints. }\end{array}$ \\
\hline & $\begin{array}{l}\overline{\frac{5}{\tilde{J}}} \\
\overline{\tilde{g}}\end{array}$ & $\begin{array}{l}\text { Construction of the venues according } \\
\text { to international standards. }\end{array}$ & $\begin{array}{l}\text { Construction of the venues according } \\
\text { to international standards. }\end{array}$ & $\begin{array}{l}\text { Construction of the venues according } \\
\text { to international standards. }\end{array}$ \\
\hline & & Enrichment of the city's sports culture. & Enrichment of the city's sports culture. & Enrichment of the city's sports culture. \\
\hline & & $\begin{array}{l}\text { A center for winter tourism and winter } \\
\text { sports. }\end{array}$ & A center for summer sports. & A center for summer sports. \\
\hline & & $\begin{array}{l}\text { Concentration of sports facilities in the } \\
\text { city center }\end{array}$ & $\begin{array}{l}\text { Dispersion of sports facilities to nearby } \\
\text { towns }\end{array}$ & $\begin{array}{l}\text { Concentration of sports facilities in the } \\
\text { city center }\end{array}$ \\
\hline & $y \stackrel{घ}{\Xi}$ & $\begin{array}{l}\text { Construction of } 10 \text { venues ( } 8 \text { new and } \\
2 \text { renovation) the scope of the Games. }\end{array}$ & $\begin{array}{l}\text { Construction of I } 5 \text { venues ( } 3 \text { new and } \\
12 \text { renovation) the scope of the Games. }\end{array}$ & $\begin{array}{l}\text { Construction of } 54 \text { venues ( I I new and } \\
43 \text { renovation) the scope of the Games. }\end{array}$ \\
\hline 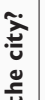 & 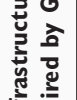 & $\begin{array}{l}\text { The re-asphalting of roads in the city } \\
\text { and landscape work. }\end{array}$ & $\begin{array}{l}\text { The re-asphalting of roads in the city } \\
\text { and landscape work. }\end{array}$ & $\begin{array}{l}\text { The re-asphalting of roads in the city } \\
\text { and landscape work. }\end{array}$ \\
\hline $\begin{array}{l}\vdots \\
\text { ¿ } \\
\end{array}$ & $\underline{\underline{J}}$ & $\begin{array}{l}\text { Construction of a curling hall, }\left.\right|^{\text {st }} \text { one } \\
\text { in Turkey. }\end{array}$ & $\begin{array}{l}\text { Construction of a Gymnastics Hall, } \text { Ist }^{\text {st }} \\
\text { one in Turkey. }\end{array}$ & $\begin{array}{l}\text { Construction of a Gymnastics Hall, } 2^{\text {nd }} \\
\text { one in Turkey }\end{array}$ \\
\hline$\overbrace{x}^{\circ}$ & & International and national competitions. & International and national competitions & International and national competitions \\
\hline 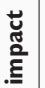 & ల్ & $\begin{array}{l}\text { One of the } 12 \text { official camping centers } \\
\text { acknowledged by the ministry. }\end{array}$ & $\begin{array}{l}\text { One of the } 12 \text { official camping centers } \\
\text { acknowledged by the ministry. }\end{array}$ & $\begin{array}{l}\text { One of the } 12 \text { official camping centers } \\
\text { acknowledged by the ministry. }\end{array}$ \\
\hline 吾 & 它 & $\begin{array}{l}\text { Camps start in the city involving winter } \\
\text { tourism and winter sports. }\end{array}$ & $\begin{array}{l}\text { Camps starts in the city involving } \\
\text { summer sports. }\end{array}$ & $\begin{array}{l}\text { Camps starts in the city involving } \\
\text { summer sports. }\end{array}$ \\
\hline & & $\begin{array}{l}\text { Vision for becoming a "Center for } \\
\text { Winter Games, "targeting income from } \\
\text { winter tourism. }\end{array}$ & & \\
\hline & 站 & $\begin{array}{l}\text { Event of campaigns'projects to develop } \\
\text { sports culture. }\end{array}$ & $\begin{array}{l}\text { Event of campaigns projects to develop } \\
\text { sports culture. }\end{array}$ & $\begin{array}{l}\text { Event of campaigns projects to develop } \\
\text { sports culture. }\end{array}$ \\
\hline & อิ & Formation of amateur sports clubs. & Formation of amateur sports clubs. & Formation of amateur sports clubs. \\
\hline & \& & Creating a variety of sports branches. & Creating a variety of sports branches. & Creating a variety of sports branches. \\
\hline & & $\begin{array}{l}\text { Less public use due to remote location } \\
\text { of some venues (Kandilli Konakli). }\end{array}$ & $\begin{array}{l}\text { Less public use due to remote location } \\
\text { of some venues (gymnastics, athletics). }\end{array}$ & $\begin{array}{l}\text { Less public use due to remote location } \\
\text { of some venues. Most of venues } \\
\text { concentrate area of the Northern } \\
\text { Mersin. }\end{array}$ \\
\hline & & Lack of training fields & Lack of training fields & Lack of training fields \\
\hline & & & $\begin{array}{l}\text { Olympic Games Press Center and office } \\
\text { built remote location of the city }\end{array}$ & $\begin{array}{l}\text { Lack of Promotion, } \\
\text { time constraint. }\end{array}$ \\
\hline
\end{tabular}


Table 14. Erzurum, Trabzon and Mersin field research-II

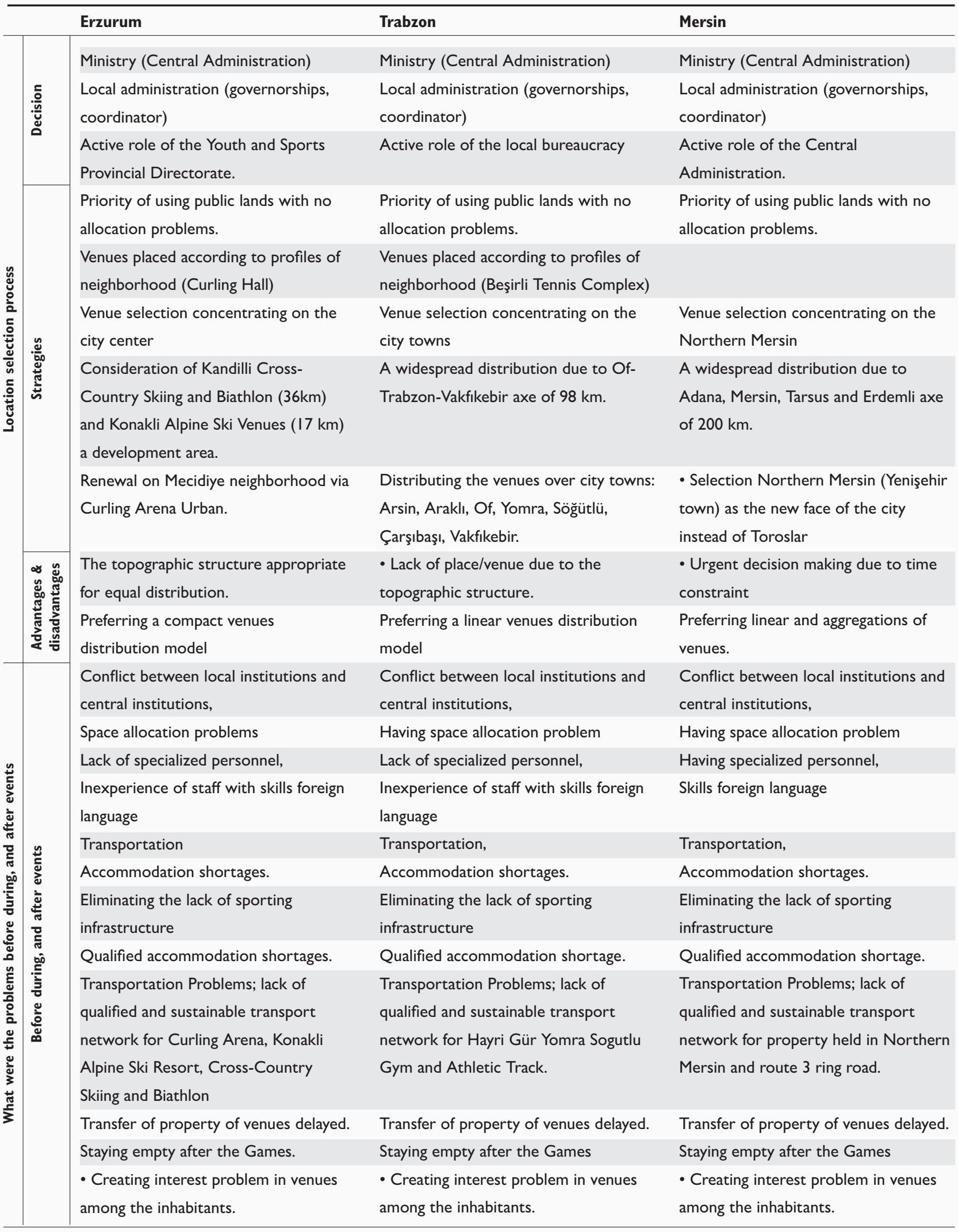


Table I5. Erzurum, Trabzon and Mersin field research III

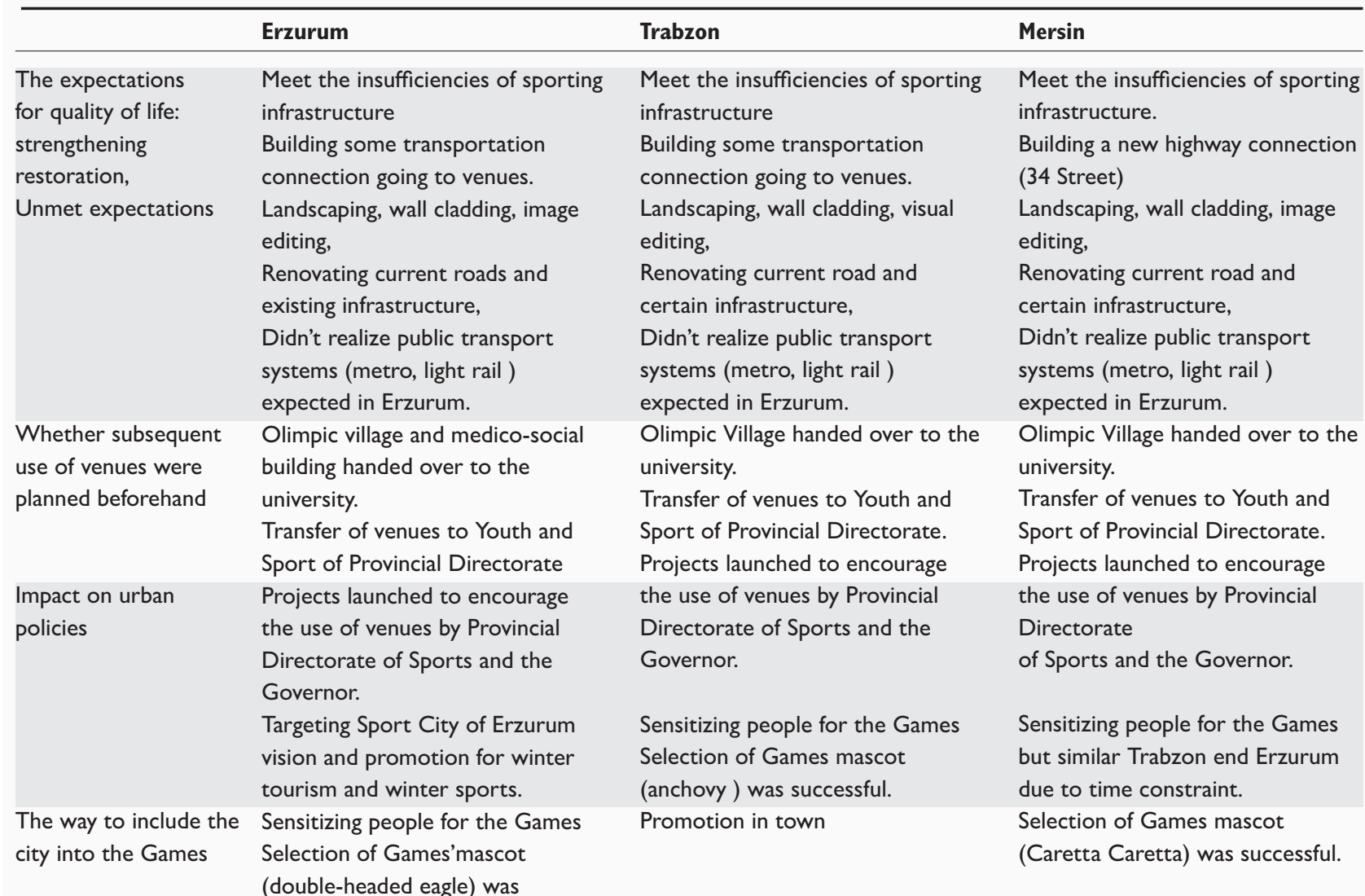

unsuccessful.

Promotion in town, and in the neighboring cities.

Concerns about the future of facilities

Fault lines, important points

Ability to use the gained infrastructure
Encouraging projects for use of facilities; opening courses and amateur clubs.

Hosting international and national competitions.

Increase in licensed number of athletes and the number of coaches.

Sports facilities used with high level occupancy,

- It is the first event for the

Winter Games,

- The idea of hosting similar events reappeared in the agenda of the government.

- Taking necessary legal steps.

-Forming a core staff for similar events,

To establish new amateur sports clubs.

Training many athletes in various branches with new amateur sports clubs.
Meet the insufficiencies of sporting structure

Landscaping, wall cladding, visual editing,

Renovating current road and anspor rail expected in Erzurum.

Olimpic Village handed over to the university.

Transfer of venues to Youth and Sport of Provincial Directorate. Projects launched to encourage the use of venues by Provincia Directorate of Sports and the Sensitizing people for the Games Selection of Games mascot (anchovy) was successful. Promotion in town

Encouraging projects for use of facilities; opening courses and amateur clubs.

Hosting international and national competitions.

Licensed number of athletes and the number of coaches increased. Sports facilities use with middle level occupancy

- The city did sport versatility,

- The city is accustomed to such events, because it hosted Ist Black Sea Games in 2007

- The event spread across the province.

Diversifying sport branches using tendency city inhabitants.

Training many athletes in various branches with new amateur sports clubs.
Encouraging projects for use of facilities; opening courses and amateur clubs.

Hosting international and national competitions.

Licensed number of athletes and the number of coaches increased. Sports facilities use with middle level occupancy

- Having a core staff involving Erzurum and Trabzon events. -Having experienced manger venues employed to event,

To establish new amateur sports clubs.

Training many athletes in various branches with new amateur sports clubs. 